\title{
IMPLEMENTASI PENDIDIKAN KEWARGANEGARAAN GENERASI MUDA SEBAGAI SMART AND GOOD CITIZEN DI ERA DISRUPSI
}

Rizka Putri Ayuning Lestari Fajar, Dinie Anggraeni Dewi

Universitas Pendidikan Indonesia Kampus Daerah Cibiru, Pendidikan Guru Sekolah Dasar

Email: rizkaputrialf@upi.edu, dinieanggraenidewi@upi.edu

\begin{abstract}
Abstact
The study aims to reflect the implementation of smart and good citizen in the disruptive era of young Indonesia as a form of implementing civic education. A qualitative approach with case-study methods is taking place in the study. Data collection techniques are done with observation and interviews. The informants in this activity are the younger generation, whether students or students, who have worked. Studies have shown that the younger generation today has become smart and good citizens, although some of them are still not smart and good citizen. The implementation of a young generation as smart and good citizen is done by becoming clear citizens of his rights and obligations. In the disruptive era, implementation of smart and good citizen is a big part of social media. Smart and good citizen takes the younger generation to be smart and wise citizens who utilize technology. Becoming smart and good citizen is achieved by learning proper and conscientious citizenship education.
\end{abstract}

Key words: Civic Education, Smart and Good Citizen, Disruptive Era, Young Generation 


\begin{abstract}
Abstrak
Penelitian ini bertujuan memberi gambaran tentang implementasi menjadi smart and good citizen di era disrupsi pada generasi muda Indonesia sebagai salah satu bentuk pengimplementasian pendidikan kewarganegaraan. Pendekatan kualitatif dengan metode studi kasus dilakukan pada penelitian ini. Teknik pengumpulan data dilakukan dengan observasi dan wawancara. Informan dalam kegiatan ini yaitu para generasi muda, baik yang menjadi mahasiswa ataupun yang telah bekerja. Hasil penelitian menunjukkan bahwa generasi muda saat ini telah menjadi smart and good citizen, walaupun beberapa dari mereka masih belum menjadi smart and good citizen. Implementasi generasi muda sebagai smart and good citizen dilakukan dengan menjadi warga negara yang paham akan hak dan kewajibannya. Pada era disrupsi, implementasi menjadi smart and good citizen banyak dilakukan di berbagai media sosial. Smart and good citizen mengantarkan para generasi muda menjadi warga negara pintar dan bijak dalam memanfaatkan teknologi. Menjadi smart and good citizen dicapai dengan mempelajari pendidikan kewarganegaraan dengan baik dan sungguh-sungguh.
\end{abstract}

Kata kunci: Pendidikan Kewarganegaraan, Smart and Good Citizen, Era Disrupsi, Generasi Muda 


\section{PENDAHULUAN}

Kemajuan teknologi tidak akan pernah hilang dan akan terus berkembang, begitupun dengan kepribadian manusia. Semakin canggihnya teknologi maka semakin pintarnya manusia dan semakin hebat pula kepribadiannya. Kemajuan teknologi melahirkan adanya sebuah era baru. Era disrupsi menjadi era yang kini tengah dijalani oleh seluruh manusia. Perubahan pada era disrupsi dapat dilihat dari teknologi komunikasi yang terus ber-gerak dengan cepat dan menjadi lebih sempurna (Sidiq, 2019). Menurut Anoegrajekti (2019) disrupsi merupakan bentuk perubahan yang dapat mengganggu kondisi masyarakat yang telah memiliki kemapanan. Fenomena disrupsi ini dalam menciptakan pola tatanan kehidupan baru yang lebih dikuasai teknologi mampu mengacak-acak pola tatanan kehidupan lama (Indriyani, 2020). Menurut Kasali (2017), disrupsi mencerminkan makna fenomena perubahan hari esok (the future change) dan tidak hanya bermakna fenomena perubahan hari ini (today change).

Era disrupsi melahirkan pola interaksi baru yang lebih kreatif, inovatif, dan massif (Malatuny, 2020). Dengan begitu, manusia saat ini dituntut untuk bisa lebih berkreasi dan berinovasi dari sebelumnya. Kreatif dan inovatif ini tidaklah hanya ditujukan untuk hal-hal positif, faktanya kreatifitas dan pikiran yang inovatif mampu membentuk suatu kejahatan baru. Seperti yang di-ungkapkan oleh Fukuyama (2000), menyatakan bahwa disrupsi ini merupakan sebuah bentuk gangguan terhadap tata sosial. Dalam bukunya, The Great Disruption (2000) Francais Fukuyama menyampaikan bahwa disrupsi menyebabkan kriminalitas terjadi di masyarakat, perubahan pandangan keluarga mengenai jumlah anak, dan menurunnya kepercaya-an masyarakat menjadi pemicu muncul-nya disrupsi sebagai perubahan besar dalam tatanan kehidupan atau tatanan sosial.

Dengan begitu, diperlukan adanya pendidikan karakter yang mampu mengatasi berbagai permasalahan yang timbul dalam era disrupsi ini. Pendidikan kewarganegaraan merupakan salah satu bidang pendidikan yang memiliki peran penting, mengingat posisinya dalam pembahasan kurikulum pendidikan nasional (Asyafiq, 2016). Kehadirannya yang di mulai dari tingkat sekolah dasar hingga perguruan tinggi, dapat dikatakan sebagai salah satu upaya yang strategis dalam membangun karakter Indoneisa yang telah menjadi negara multikultur (Hartini, 2020). Adanya pendidikan kewarganegaraan ini akan membentuk karakter warga negara yang smart and good sesuai dengan nilai-nilai kebangsaan Indonesia yaitu Pancasila dan juga UUD 1945.

Bangsa Indonesia memiliki cita-cita yang tertuang dalam pembukaan UndangUndang Dasar 1945, yaitu "mencerdaskan kehidupan bangsa", mengacu pada citacita inilah konsep pendidikan kewarganegaraan dirancang sesuai dengan tujuan pendidikan nasional dan tidak bertentangan dengan dasar negara Pancasila (Febriansyah, 2017). Sesuai dengan tujuan 
yang tercantum dalam Depdiknas, yaitu pendidikan kewarganegaraan dituju-kan untuk mempersiapkan para generasi muda dapat menjadi warga negara yang baik, kritis dan kreatif, memiliki kecapkapan ilmu pengetahuan dan nilai-nilai luhur yang dapat digunakan untuk berperan aktif dan penuh kesadaran me-ngikuti kegiatan kemasyarakatan (Setiawan, 2019).

Dari sinilah, dapat pula dilihat bahwa pendidikan kewarganegaraan dapat membentuk smart and good citizen. Namun, dalam pelaksanaannya di era disrupsi ini diperlukan stimulus baru (Syam, 2019). Sangat penting dan sangat dibutuhkan menjadi smart and good citizen di era disrupsi seperti ini untuk menghindari ber-bagai ancaman kejahatan. Kini di Indonesia telah banyak yang menjadi smart and good citizen namun tentu terdapat pula warga negara yang sebaliknya dan hal ini terlihat dari berbagai komentar buruk atau ujaran kebencian di media sosial dan penyebaran informasi palsu.

Generasi muda pun harus ikut serta menjadi smart and good citizen di era disrupsi ini. Pada era disrupsi ini generasi muda atau generasi milennial lah yang banyak memegang peranan. Perubahan yang terjadi saat ini memerlukan suatu contoh dan panutan yang dapat membawa masyarakat ke arah yang lebih baik lagi, dan generasi muda lah yang mampu mem-bawa arah kebaikan itu, karena generasi muda adalah tonggak keberlangsungan masa depan Indonesia (Ikhtiarti, dkk., 2019). Penanaman menjadi warga negara yang baik pada generasi muda menjadi perhatian utama, pengembangan menjadi warga negara yang bertanggungjawab, efektif, dan terdidik menjadi tugas paling penting menurut Budimansyah (2010).

Menjadi smart and good citizen dapat diimplementasikan melalui media sosial yang sangat dikuasai oleh generasi muda saat ini. Media sosial memiliki peluang yang sangat dahsyat di era disrupsi, gagasan-gagasan yang diunggah di media sosial tidak hanya bergema di media sosial itu saja, tetapi juga mampu membawa konkret terhadap kehidupan nyata secara faktual (Mu'ammar, 2019).

Mengimplementasikan diri sebagai smart and good citizen merupakan suatu bentuk pengimplementasian pendidikan kewarganegaraan.

\section{METODE PENELITIAN}

Penelitian ini menggunakan pendekatan kualitatif dengan metode studi kasus untuk memaknai implementasi pendidikan kewarganegaraan yang dilakukan generasi muda sebagai smart and good citizen di era disrupsi. Studi kasus merupakan suatu kegiatan ilmiah yang terstruktur, rinci dan mendalam untuk mendapatkan informasi tentang sebuah kasus yang sedang atau telah terjadi melalui suatu program, aktivitas, peristiwa di dalam suatu kelompok, lembaga atau organisasi (Rahardjo, 2017). Tulisan ini disusun berdasarkan pengumpulan data yang dilakukan dengan observasi, 
wawancara dan studi dokumentasi berupa pengumpulan data-data yang berkaitan dengan judul penelitian (Sugiyono, 2011).

Observasi dilakukan di lingkungan nyata yaitu daerah Kota Bandung dan lingkungan maya di media sosial untuk mengetahui keadaan sebenarnya bagai-mana tingkah laku generasi muda dalam kegiatan sehari-harinya. Wawancara dilakukan terhadap beberapa informan meliputi generasi muda yang menjadi mahasiswa dari beberapa universitas dan generasi muda yang telah bekerja guna memperoleh data terkait pengetahuan dan pengimplementasian mereka mengenai smart and good citizen. Teknik analisis data dilakukan mengikuti konsep Sugiyono (2013) yaitu reduksi data, sajian data, pe-narikan kesimpulan dan verifikasi untuk men-jelaskan data penelitian terkait implementasi smart and good citizen oleh generasi muda di era disrupsi.

\section{HASIL DAN PEMBAHASAN}

Generasi muda dijadikan sebagai tonggak keberlangsungan masa depan Indonesia (Budimansyah, 2010). Namun, pengetahuan mengenai smart and good citizen di kalangan generasi muda nyatanya belum begitu terkenal. Smart and good citizen artinya yaitu warga negara yang cerdas dan baik. Smart and good citizen ini merupakan hasil akhir yang diharapkan ketika ketiga komponen utaman pendidikan kewarganegaraan yang dilaksanakan dengan baik. Ketiga komponen pendidikan kewarganegaraan tersebut adalah civic knowledge

(pengetahuan

kewarganegaraan),

civic

skills

(keterampilan kewarganegaraan) dan civic dispositions (sikap kewarganegaraan) (Arliman, 2020).

Beberapa generasi muda di Kota Bandung ini masih memiliki pengetahuan yang minim mengenai smart and good citizen padahal mereka telah mempelajari pendidikan kewarganegaraan di sekolah. Namun, tidak sedikit pula terdapat generasi muda yang mengetahui smart and good citizen dan hubungannya dengan pendidikan kewarganegaraan. Bagi generasi muda yang tidak mengetahui smart and good citizen ternyata mereka menyadari bahwa dirinya belum mengimplementasikan nilai-nilai pendidikan kewarganegaraan dengan optimal dan juga merasa bahwa dirinya belum menjadi warga negara yang baik.

Permasalahan seperti itulah yang menjadi kasus bagi bangsa Indonesia yang harus segera diselesaikan. Dengan adanya kesadaran pada masing-masing individu bahwa mereka belum menjadi warga negara yang baik maka mudah bagi generasi muda lainnya untuk meningkatkan atau menstimulus kembali kesadaran-kesadaran generasi muda dalam menjadi smart and good citizen $\mathrm{di}$ kehidupan sehari-harinya. Kini pemenuhan kebutuhan informasi dan gaya interaksi generasi muda bergerak mengikuti kecanggihan teknologi (Malatuny, dkk., 
2020). Hal ini ditandai dengan intensitas yang tinggi penggunaan jaringan internet. Dengan memanfaatkan jaringan internet ini, setiap generasi muda dapat mencari informasi mengenai smart and good citizen yang dihubungkan dengan pendidikan kewarganegaraan. Dengan meng-akses jaringan internet juga, para generasi dapat membantu meningkatkan kesadaran generasi muda lainnya untuk menjadi smart and good citizen. Hal ini dapat dilakukan melalui berbagai media sosial, seperti Whatsapp, Instagram, Youtube, Twitter, Tiktok.

Kondisi pemenuhan kebutuhan informasi dan gaya interaksi yang kini dilakukan melalui kecanggihan teknologi merupakan ciri dari adanya era disrupsi. Pada era disrupsi perubahan yang terjadi dalam kehidupan sangatlah besar dan bersifat mendasar dengan sangat cepat tanpa bisa ditahan lajunya (Hapsari, 2019). Era disrupsi memberikan manfaat berupa kemudahankemudahan dalam kehidupan seperti yang telah disebutkan sebelumnya. Pencarian informasi dan interaksi antar manusia menjadi lebih efektif. Namun, dibalik kemanfaatannya cukup besar, era disrupsi pun memberikan dampak negatif pada manusia, dampak negatif inilah yang dapat menjadikan generasi muda tidak menjadi smart and good citizen dan dapat membuat lunturnya nilai-nilai kewarganegaraan mereka yang selama ini dipelajari.

Generasi muda saat ini atau dapat disebut sebagai generasi $\mathrm{Z}$ memiliki karakteristik produktif dalam memanfaatkan internet dan media sosial dan dikenal sebagai generasi yang mandiri dan pintar, karena mereka tidak perlu menunggu orangtua untuk mengajari hal-hal baru dan atau membuat keputusan, mereka mampu untuk belajar sendiri (Fitriyani,2018). Dari pengertian tersebut sangatlah relevan dengan karakteristik generasi muda di lapangan. Generasi muda di Kota Bandung memiliki kemandirian dan kepintaran yang cukup tinggi, mereka mampu memanfaatkan teknologi untuk mencari berbagai informasi. Generasi muda saat ini nyatanya telah mampu mengidentifikasi perilaku warga negara yang kurang baik dan mereka pun telah mampu memikirkan upaya yang dapat dilakukan untuk mengurangi atau menjadikan warga negara yang kurang baik menjadi baik dan juga pintar.

Berdasarkan hasil penelitian yang dilakukan, para generasi muda berpendapat bahwa smart and good citizen itu merupakan warga negara yang (1) memahami akan hak dan kewajiban, dalam hal ini warga negara memahami konsep benar dan salah, baik dan buruk serta konsep sesuatu yang harus dilakukan dan tidak harus dilakukan. Hak dan kewajiban dapat berkaitan dengan hak dan kewajiban pada negara artinya disini manusia berkedudukan sebagai warga negara. Terdapat pula hak asasi manusia, disini manusia berkedudukan sebagai makhluk sosial. Hak dan kewajiban warga negara 
sebenarnya mencakup hak asasi manusia pula, sehingga pelaksanaannya haruslah dilakukan dengan baik. Dalam pelaksana-annya maka diperlukan adanya sikap tolerasi, saling menghargai dan menghormati satu sama lain. (2) Mengetahui dan memahami nilai-nilai luhur bangsa yaitu Pancasila, dalam hal ini sebagai smart and good citizen berarti haruslah mengetahui dan memahami akan makna pada setiap sila Pancasila yang menjadi nilai-nilai luhur bangsa. Selain itu, perlu juga melakukan penghayatan dan penanaman dalam diri agar nilai-nilai luhur Pancasila ini melekat pada sanubari warga negara sehingga dalam menjalankan kegiatan sehari-harinya dapat sesuai dengan nilai-nilai Pancasila. Segala bentuk kegiatan yang didasari dengan nilai-nilai luhur Pancasila akan memberikan pengaruh positif yang besar pada seluruh aspek kehidupan.

(3) Mampu menegakan hukum, dalam hal ini sebagai smart and good citizen harus memiliki kemampuan untuk mengkritisi segala kebijakan atau peraturan yang ada sebelum menjalankan atau menaatinya dengan baik. Untuk menegakkan hukum, diperlukan adanya penegakkan keadilan, karena hukum dan keadilan memiliki keterkaitan yang sangat erat. Hukum yang tidak berjalan seperti semestinya merupakan hukum yang tidak menjunjung keadilan dan kebenaran. (4) Mampu menjaga ketahanan nasional, dalam hal ini smart and good citizen mampu menjaga kesatuan dan keutuhan bangsa. Menjadi smart and good citizen tidaklah menjadi individu yang senang memecah belah persatuan bangsa dengan segala tindakannya, namun haruslah menjadi warga negara yang senantiasa selalu berpartisipasi menjaga dan membela negaranya. (5) Memiliki ide-ide kreatif dan inovatif serta selektif, dalam hal smart and good citizen memiliki cara berpikir yang kreatif dan inovatif dalam memandang sesuatu. Sebagai smart and good citizen artinya mampu secara aktif menyalurkan ide-ide kreatif dan inovatifnya untuk memajukan, mencerdaskan dan mengembangkan bangsa. Smart and good citizen pun dituntut untuk selektif dalam menerima berbagai informasi dan budaya dari luar. Selektif dalam menerima informasi dapat menjaga keutuhan bangsa, karena tidak jarang terdapat informasi yang palsu dan budaya luar yang tidak sesuai dengan jati diri bangsa, sehingga mampu memecah belah kesatuan dan keutuhan bangsa.

Adapula warga negara yang tidak pintar dan tidak baik di era disrupsi ini menurut para generasi muda yaitu warga negara yang senantiasa mudah mempercayai dan menyebarluaskan informasi palsu atau hoax, bahkan terdapat warga negara yang membuat sendiri informasi palsu tersebut. Kemunculan hoax di berbagai media sosial yang sulit untuk dihentikan dan mampu membuat masyarakat resah dan mampu memecahkan kesatuan bangsa (Malatuny, 2020). Kementerian Komunikasi dan Informasi 
(Kominfo) mencatat pada tahun 2017 terdapat sekitar 800.000 situs yang menyebarkan hoax atau berita bohong.

Pada tahun 2020 di mana sedang terjadi pandemi terdapat sekitar kurang 1.028 hoax mengenai pandemi Covid-19 beredar dan jumlah itu hanya jumlah hoax pandemi saja, belum dengan informasi-informasi bohong lainnya. Jika pada kedua tahun tersebut telah memiliki jumlah informasi hoax yang cukup banyak maka pada tahun ini dapat dipastikan jumlah informasi hoax meningkat. Informasi hoax menjadi salah satu masalah pada era disrupsi yang sangat sulit untuk diatasi akibat dari laju jaringan internet yang sangat cepat. Dari adanya informasi hoax ini memicu terjadinya per-pecahan, sebagai contoh terdapat informasi hoax terkait kebijakan pemerintah, tentu hal ini akan merusak kepercayaan warga negara pada pemerintah. Rusaknya kepercayaan warga negara akan menimbulkan tuntutan warga negara pada pemerintah dan terjadilah kesalah-pahaman.

Selain itu, adanya era disrupsi ini membuat warga negara terlalu nyaman hingga terlena dengan teknologi sehingga dapat menyepelekan pendidikan bahkan meninggalkan pendidikan dan meninggalkan budayabudaya lokal karena terpengaruh globalisasi. Saat ini, banyak sekali siswa ataupun mahasiswa yang telah dibudaki oleh teknologi seperti games online, media sosial, situs-situs yang tidak baik seperti pornografi dan kekerasan. Hal ini akan mempengaruhi pendidikannya. Banyak para generasi muda dilapangan yang telah dibudaki oleh games online dan media sosial sehingga mereka cenderung bermalas-malasan dalam belajar, bahkan di tempat umum dalam pergaulannya pun mereka sulit untuk lepas dari gadget-nya. Banyaknya generasi muda yang mengakses situs-situs berbahaya seperti ponografi dan kekerasan, hal ini berdampak pada psikologis dirinya. Di lapangan telah banyak terjadi kasus tindakan asusila dan kekerasan. Telah banyak warga negara yang kehilangan akalnya akibat terlalu sering mengakses situs-situs berbahaya tersebut.

Banyak pula warga negara yang mengumbar perilaku dan ujaran negatif di media sosial. Hal ini dapat dilihat banyaknya pemberitaan-pemberitaan mengenai warga negara yang terjaring pasal UU ITE. Warga negara seperti ini merupakan warga negara yang tidak pernah berpikir terlebih dahulu sebelum melakukan sesuatu. Mereka dengan mudahnya menyebarluaskan video-video tidak pantas dan tidak sesuai dengan nilai moral yang ada serta dengan mudahnya mengeluarkan kata-kata yang menghina dan menghujat kepada orang lain. Selain adanya pelanggaran di dunia maya, adapula pelanggaran di dunia nyata yang banyak dilakukan generasi muda saat, diantaranya masih terjadi pelanggaranpelanggaran peraturan, seperti adanya pelanggaran aturan lalu lintas dengan tidak 
menggunakan helm dan tidak mengikuti aturan protokol kesehatan di masa pandemi.

Pada intinya warga negara yang tidak pintar dan tidak baik merupakan warga negara yang tidak paham akan kewajibannya sebagai warga negara dan tidak paham akan nilai-nilai luhur Pancasila. Para warga negara yang tidak pintar dan tidak baik ini dapat dipastikan merupakan bagian dari warga negara yang tidak memahami dan tidak meng-implementasikan pendidikan kewarga-negaraan.

Dari banyaknya materi pembahasan dalam pendidikan kewarganegaraan, dari hasil penelitian generasi muda di Kota Bandung ini lebih banyak mengimplementasikan materi hak asasi manusia, penegakan hukum, ketahanan nasional, demokrasi dan membangun bangsa. Pengimplementasian ini tentunya membuktikan bahwa generasi muda di Kota Bandung telah menjadi smart and good citizen. Pada era disrupsi saat ini, pengimplementasian pendidikan kewarganegaraan yang dilakukan oleh generasi muda sebagai smart and good citizen, lebih banyak dilakukan di media sosial. Dengan adanya media sosial, maka interaksi dalam berbangsa dan bernegara menjadi sangat luas, kebebasan berekpresi dan berpendapat pun menjadi sangat bebas.

Implementasi pendidikan kewarganegaraan yang dilakukan generasi muda di di era disrupsi ini diantaranya. (1) Menjalankan HAM dengan baik. Dalam hal ini generasi muda telah dapat menghargai dan menghormati pendapat orang lain, hal ini dilakukan dengan tidak memberikan komentar negatif pada unggahan orang lain di media sosial, hal ini pun dilakukan di lingkungan nyata seperti di kelas saat pembelajaran, di sebuah organisasi atau saat sedang berkumpul dengan teman-teman dekat mereka. Tidak sedikit dari generasi muda yang mengeluarkan pendapat-pendapatnya terkait dengan isu-isu kewarga-negaraan, kebangsaan dan kenegaraan saat ini serta melakukan diskusi untuk mencari solusi akan isu-isu tersebut. Hal ini membuktikan bahwa generasi muda saat ini telah menjadi smart and good citizen. Selain itu, generasi muda pun telah menjalankan toleransi. Dengan adanya media sosial membuat generasi muda lebih mudah mengetahui suku, agama, ras, dan antargolongan yang lain, hingga sebagai smart and good citizen, generasi muda selalu menghargai setiap perbedaan yang ada. Menghargai perbedaan ini biasa dilakukan dengan tidak rasis, tidak melakukan tindak kekerasan, tidak melakukan tindakan yang semena-mena, menjunjung tinggi keadilan, saling menghargai, meng-hormati dan tolong menolong satu sama lain, serta menerapkan tata krama sosial. Semua hal yang dilakukan oleh generasi muda disini merupakan cakupan nilai-nilai yang terkandung dalam Pancasila.

(2) Melakukan penegakan hukum. Para generasi muda ini telah berusaha melakukan berbagai tindakan yang menegakkan hukum, mereka 
senantiasa menaati segala peraturan yang ada. Generasi muda saat ini telah banyak yang senantiasa memberikan contoh yang baik sebagai warga negara agar dapat ditiru oleh warga negara lainnya. Ketika terdapat kebijakan baru dari pemerintah, sebelum generasi muda menjalankan kebijakan tersebut dengan baik, mereka pun senantiasa akan mengkritisi dan memahami terlebih dahulu kebijakan-kebijakan yang ada. Kemudian, jika menurut mereka terdapat suatu kesalahan dalam kebijakan tersebut mereka akan senantiasa menyalurkan aspiranya demi terciptanya suatu hukum yang benar. Hal ini pun telah terbukti ketika terdapat aksi demo mengenai UU Cipta Kerja pada tahun lalu. Dapat dilihat dalam aksi demo ini seluruh generasi muda melakukan tindakan untuk menegakkan hukum baik secara langsung di lapangan ataupun melalui dunia maya di media sosial. Di dunia maya pun generasi muda melakukan tindakan yang sesuai dengan hukum UU ITE yang berlaku. Generasi muda saat ini telah banyak yang memahami bagaimana cara menggunakan media sosial atau jejaring internet dengan baik. Telah banyak generasi muda yang tidak mudah termakan oleh informasi palsu atau hoax, mereka mampu selektif dalam memilih informasi dan mampu mengkritisi terlebih dahulu informasi-informasi yang baru. Di media sosial pun, mereka tidak pernah memberikan komentar-komentar negatif ataupun mengirimkan unggahan-unggahan negatif, generasi muda saat ini senantiasa mengunggah unggahan yang positif yang dapat membangun karakter warga negara yang pintar dan baik. Dengan teknologi ini pun, mereka memanfaatkan teknologi untuk mempelajari dan memperluas wawasan.

(3) Menjaga ketahanan nasional. Di era disrupsi seperti ini, tindakan generasi muda untuk menjaga ketahanan nasional yaitu dengan tidak mudah mempercayai dan tidak menyebarluaskan informasi palsu atau hoax. Seperti yang telah disinggung pada poin sebelumnya bahwa generasi muda saat ini senantiasa mengkritisi atau menggali lebih dalam terlebih dahulu terkait informasi-informasi yang baru ia terima. Selain itu, untuk menjaga ketahanan nasional generasi muda mampu bersikap terbuka terhadap hal baru namun juga bersikap selektif dalam menerima hal baru tersebut. Selektif disini berupa memilih dan memilah hal-hal baru yang sesuai dengan nilai-nilai budaya Indonesia. Dukungan yang generasi muda berikan untuk bangsa Indonesia ini yaitu berupa mendukung usaha-usaha produk lokal demi menjaga eksistensi budaya Indonesia. Generasi muda pun senantiasa menjaga kesatuan dan keutuhan bangsa dengan melakukan hak dan kewajibannya sebagai warga negara dengan baik.

(4) Menjunjung tinggi demokrasi. Bukti bahwa generasi muda menjunjung tinggi demokrasi ini dapat terlihat dari banyak para generasi muda yang berkumpul untuk melakukan diskusi atau musyawarah demi terciptanya suatu keputusan akan sesuatu. Sebelum 
melakukan sesuatu, generasi muda saat ini senantiasa meminta pendapat orang lain terlebih dahulu dan hal ini terjadi baik di dunia nyata ataupun di dunia maya. Telah dibahas pula pada sebelumnya bahwa, generasi muda saat ini memiliki jiwa menghargai dan menghormati pendapat orang lain sehingga generasi muda saat dapat dikatakan sebagai smart and good citizen yang mampu menjunjung tinggi nilai demokrasi. (5) Memiliki pemikiran atau sikap kreatif dan inovatif. Sesuai dengan tuntusan era disrupsi yaitu setiap manusia diharuskan memiliki pemikiran atau sikap yang kreatif dan inovatif. Kini banyak generasi muda yang memiliki pemikiran ataupun sikap kreatif dan inovatif untuk membangun bangsa. Hal ini terbukti dengan banyaknya usaha-usaha kecil menengah yang unik dan munculnya teknologiteknologi sederhana baru yang berguna bagi masyarakat luas. Dalam membangun karakter warga negara sendiri pun, generasi muda memiliki cara yang kreatif dan inovatif yaitu dengan me-nyosialisasikan suatu pengetahuanpengetahuan kewarganegaraan dengan mediamedia yang menarik dan adanya sejumlah aplikasi yang mengedukasi.

Generasi muda saat ini dapat dikatakan sebagai smart and good citizen yang memahami dan melaksanakan hak serta kewajibannya sebagai warga negara sesuai dengan nilai-nilai Pancasila. Walaupun telah banyak generasi muda yang menjadi smart and good citizen, namun masih pula terdapat generasi muda yang belum menjadi smart and good citizen. Disinilah tugas utama generasi muda di era disrupsi untuk mampu berkomitmen dalam menjadi smart and good citizen sepanjang hayatnya dan mampu membantu bangsa meningkatkan kesadaran generasi muda lainnya untuk menjadi smart and good citizen dengan memanfaatkan pendidikan kewarganegaraan.

Upaya yang dilakukan untuk merubah warga negara yang kurang baik berhubungan dengan pengimplementasian pendidikan kewarganegaraan. Pendidikan kewarga-negaraan telah diajarkan mulai dari tingkat sekolah dasar hingga perguruan tinggi. Dalam pengimplementasian pendidikan kewarganegaraan sehari-hari harus dilakukan sepanjang hayat. Hal ini dikarenakan, warga negara akan selalu bertambah setiap harinya, sehingga untuk menciptakan generasi warga negara yang berkualitas haruslah diawali dengan pengimplementasian nilai-nilai pendidikan kewarganegaraan secara terus-menerus. Pendidikan kewarganegaraan perlu beririsan atau terintegrasi dengan isu-isu sosial kemasyarakatan, mampu mengembangkan karakter dan moral bangsa, hingga harus relevan dengan kemajuan zaman (Erfiana \& Ariyanto, 2020). Dengan begitu, dalam pengimplementasian pendidikan kewarganegaraan ini akan terus berkembang mengikuti zaman dan isu-isu terbarukan yang ada di masyarakat. 
Upaya yang dapat dilakukan oleh generasi muda untuk membentuk smart and good citizen yaitu dengan selalu memberikan contoh yang baik menjadi warga negara, senantiasa mengingatkan atau menyosialisasikan kepada generasi muda lainnya untuk menjadi warga negara yang pintar dan baik melalui media sosial. Hal ini dapat dilakukan dengan menyebarkan pengetahuanpengetahuan umum yang ada di dalam pendidikan kewarganegaraan, membuat videovideo yang membangun kecintaan pada tanah air, menyebarkan unggahan-unggahan terkait kebangsaan yang tentunya bukan suatu informasi palsu atau hoax. Selain itu, generasi muda pun dapat mengajak generasi muda lainnya untuk bertukar pikiran atau berdiskusi mengenai warga negara bangsa Indonesia, saling berbagi ilmu dan saling mengingatkan jika terdapat generasi muda yang melakukan kesalahan.

Sebagai generasi yang produktif, maka generasi muda haruslah produktif dalam membangun bangsa Indonesia, khususnya membangun karakter warga negara Indonesia untuk menjadi smart and good citizen. Jiwa semangat yang berkobar dalam diri generasi muda haruslah dimanfaatkan dengan baik untuk menyebarkan kebaikan dan menyebarkan pegetahuan-pengetahuan yang bermanfaat khususnya pengetahuan mengenai kewarganegaraan. Perlu adanya kerja sama antar generasi muda agar dapat membangun bangsa Indonesia menjadi bangsa yang hebat. Banyaknya teknologi di era disrupsi pun harus dimanfaatkan dan digunakan sebaik dan sebijak mungkin hingga tidak menganggu kesatuan dan keutuhan bangsa.

\section{KESIMPULAN}

Kota Bandung telah memiliki banyak generasi muda yang memahami akan makna smart and good citizen, generasi muda ini pun telah mengimplementasikan dengan baik tindakan-tindakan smart and good citizen baik di lingkungan nyata ataupun maya seperti media sosial. Para generasi muda telah memahami nilai-nilai yang terkandung dalam pendidikan kewarganegaraan dan dibuktikan dengan mengimplementasikan nilai-nilai tersebut dalam kehidupan sehari-hari sebagai smart and good citizen. Pendidikan kewarganegaraan memiliki pengaruh yang sangat besar dalam membentuk smart and good citizen. Jika para generasi muda mempelajari pendidikan kewarganegaraan dengan sungguh-sungguh maka mudah bagi mereka untuk menjadi smart and good citizen.

Para generasi muda haruslah menjadi smart and good citizen demi menggapai kelangsungan bangsa yang maju. Era disrupsi haruslah dijadikan sebagai era kejayaan yang dipenuhi dengan warga negara yang berkarakter baik, pintar, kreatif, inovatif dan produktif dalam mengembangkan bangsa. Generasi muda di era disrupsi ini harus pula 
memiliki pemikiran yang dipenuhi dengan pengetahuan-pengetahuan kewarganegara-an agar kelak mereka mampu menjadi pemimpin yang paham akan warga negaranya dan bangsanya serta mampu menjadi warga negara yang paham akan hak dan kewajibannya. Oleh karena itu, para generasi muda yang menjadi smart and good citizen akan menambah pengetahuannya mengenai smart and good citizen dengan banyak membaca literatur lain, agar dapat membandingkan dan juga mengkritisi dengan baik bagaimana smart and good citizen yang sebenarnya.

\section{DAFTARPUSTAKA}

Anoegrajekti, N. (2019). Dinamika Literasi Budaya pada Era Disrupsi. In Seminar Nasional Literasi (Vol. 4, No. 1).

Arliman, L. (2020). Tantangan Pendidikan Kewarganegaraan Pada Revolusi 4.0. Ensiklopedia Sosial Review ,2(3), 333-339.

Asyafiq, S. (2016). Berbagai Pendekatan Dalam Pendidikan Nilai dan Pendidikan Kewarganegaraan. Jurnal Dimensi Pendidikan Dan Pembelajaran, 4(1), 29-37.

Budimansyah, D dan Suryadi, K. (2010). PKn dan Masyarakat Multikultural. Bandung. Universitas Pendidikan Indonesia.

Erfiana, N. A. N. E., \& Ariyanto, A. (2020). Restrukturisasi Pendidikan Kewarganegaraan Sebagai Langkah Menghadapi
Era Disrupsi. Al- Asasiyya: Journal of Basic Education, 5(1), 79-95.

Febriansyah, F. I. (2017). Ideology of Pancasila as Legal Ideas (Rechtsidee) for Indonesia Nation. International Conference on Islamic Education (ICIE), 1(1).

Fitriyani, P. (2018). Pendidikan Karakter Bagi Generasi Z. Prosiding Konferensi Nasional Ke-7 Asosiasi Program Pascasarjana Perguruan Tinggi Muhammadiyah Aisyiyah (APPPTMA). Jakarta, 23-25.

Fukyama, F. (2000). The Great Disruption: Human Nature and Reconstitution of Social Order. Profile Books.

Ikhtiarti, E., Adha, M. M., \& Yanzi, H. (2019). Membangun Generasi Muda Smart and Good Citizenship Melalui Pembelajaran Ppkn Menghadapi Tantangan Revolusi Industri.

Indriyani, D. (2020, September). Citizenship Education: Modal di Era Disrupsi. In Seminar Nasional Kewarganegaraan (Vol. 2, pp. 4346).

Hartini, S., Siregar, M., \& Arifi, A. (2020). Implementasi Pendidikan Karakter di MTs Negeri Kabupaten Klaten. Al-Asasiyya: Journal of Basic Education, 4(1), 14-29. 
Hapsari, D. (2019). Tantangan Perpustakaan

Perguruan Tinggi di Era Disrupsi.

Pustakaloka, 11(1), 151-160.

Kasali, R. (2017). Disruption. Gramedia Pustaka Utama.

Malatuny, Y. G., Labobar, J., \& Labobar, B. (2020). Literasi Media:

Preferensi Warga Negara Muda di Era Disrupsi. Journal of Moral and Civic Education, 4(1), 42-51.

Mu'ammar, M. A. (2019). Literasi di Era Disrupsi.

Rahardjo, M. (2017). Studi Kasus Dalam

Penelitian Kualitatif: Konsep dan

Prosedurnya. Malang: Universitas

Islam Negeri Maulana Malik

Ibrahim.

Setiawan, D. (2019). Rekonseptualisasi Pendidikan Kewarganegaraan di Era Revolusi Industri 4.0. Prosiding Seminar Nasional "Reaktualisasi Konsep Kewarganegaraan Indonesia" 1, 15-24.

Sugiyono. (2011). Metode Penelitian

Kuantitatif, Kualitatif, dan $R \& D$. Bandung: CV Alfabeta.

Sugiyono. (2013). Metode Penelitian

Kuantitaif, Kualitatif, dan $R \quad \& \quad D$.

Bandung: CV Alfabeta.

Syam, A. R. (2019). Guru dan Pengembangan Kurikulum Pendidikan Agama Islam di Era Revolusi Industri 4.0. Tadris: Jurnal Pendidikan Islam, 14(1), 1.
Viska. (2020, Agustus). Kominfo Mencatat Sebanyak 1.028 Hoaks Tersebar Terkait Covid-19. Kementerian Komunikasi dan Informasi Republik Indonesia.

[Diakses 25 Maret 2021].

Tersedia: https://kominfo.go .id/content/detail/kominfo-

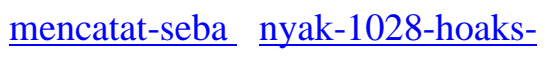
tersebar-terkait-covid1 9-sorotanmedia. Yuliani, Ayu. (2017, Desember). Ada 800.000 Situs Penyebar Hoaks di Indonesia. Kementerian Komunikasi dan Informatika Republik Indonesia. [Diakses 25 Maret 2021]. Tersedia: https://kominfo.go.id/content/detail/ 12008/ada-800000-situs-penyebarhoax-di-indonesia/0/sorotan media. 